\title{
Job Satisfaction among the Bankers: An investigation on Islamic Financial Institution in Eastern Region of Malaysia
}

\author{
Norudin Mansor ${ }^{1}$, Jannah Munirah Mohd Noor ${ }^{1} \&$ Nik Fakrulhazri Nik Hassan ${ }^{1}$ \\ ${ }^{1}$ Falcuty of Business Management, Universiti Teknologi Mara, Terengganu, Malaysia \\ Correspondence: Norudin Mansor, Falcuty of Business Management, Universiti Teknologi Mara (UiTM) \\ Dungun Campus, 23000 Dungun, Terengganu, Malaysia. E-mail: norudinm@tganu.uitm.edu.my
}

Received: March 12, $2012 \quad$ Accepted: April 23, $2012 \quad$ Published: August 1, 2012

doi:10.5539/ass.v8n10p186

URL: http://dx.doi.org/10.5539/ass.v8n10p186

\begin{abstract}
For the past few decades numerous studies attempted to explore the relative importance of understanding job satisfaction. Realizing the need to sustain in the banking industry, this study was conducted for exploring the antecedents to the strengthening of job satisfaction. Further examination on differences between the work position, work experience as related to job satisfaction is expected to form the basis for understanding the satisfaction level of banking staffs. By adopting the survey approach, a sample of 236 data were collected within the period of two months in year 2009. Based on rigorous reviewing of the literature, instrument designing, followed by subsequent pilot testing, the final analysis revealed that job satisfaction can be predicted by using motivational factors, reward system, supervision/leadership, nurturing of working environment, and the competition climate within the industry.
\end{abstract}

Keywords: job satisfaction, motivational factors, rewards systems, supervision, work environment, competition

\section{Introduction}

Currently there are many interests from different sectors in studying the factors contributing to job satisfaction especially as it is expected to lead toward better quality work performance and higher commitment from workers. The job satisfaction issues are placed high across industries but there was very little research was done on the financial institutions employees. Job satisfaction basically indicated the health of an organization. Hoppock (1932) first defined the term as circumstances combination of psychological, physical and environmental that cause an employee to state his feeling on any tasks or events associated with. Locke (1976) defines job satisfaction as the resulting positive emotional feeling due to one's evaluation of their job or job experiences by comparing one's expectation from the job and what he actually gets. Smith et. al. (1969) defines job satisfaction as an individual's emotional reaction or feeling toward certain aspects of the work environments.

In the services sector such as banking, effective services rendition largely depend on the workforce (Fitzgerald et. al, 1994) and therefore job satisfaction experience by the bank employees will affect the services quality rendered. Bank Islam Malaysia Berhad (BIMB) has been in existence since $1^{\text {st }}$ July 1983 with the aim to provide constant dedication to serve the best in Islamic Banking. Their vision is to be the Global Leader in Islamic Banking.

BIMB pioneered the new system of banking conforming towards totally "Shariah" requirements. Since its conception, it has played pivotal role in building a viable Islamic banking system to exist parallel as well as compliment the conventional banking system. Since its success, it can be seen that more banks have embraced the inclusion of Islamic Banking in their operation such as Maybank Islamic, HSBC Islamic Banking, Hong Leong Islamic and RHB Islamic. BIMB was chosen as the subject of the survey due to the fact that it has been in existence since 27 years ago as Malaysia's first Islamic banking service provider. With the total number of 3,500 employees in total as well around 350 employees are in the Eastern Region of Peninsular Malaysia, the study aimed to establish the current level of satisfaction of its employees in relation to selected criteria.

\section{Problem Statement}

Since 1997/98 Asian Financial Crisis, the Malaysian banking scenario has changed significantly. Most banks have been merged to improve efficiency and ensure survivability. In this regard, systematic mergers were done 
to 54 pre-crisis Malaysian domestic banks into 10 domestic post-crisis bank groups. Since the successful bank consolidations in 2001, BNM reported greater technology embracement, better product innovation, marked improvement in operating efficiency and better risk management system adoption (Aziz, 2004; Bowers et. al., 2003). In addition, the bank also faces threats of globalization and increasing competitions. Banks have adopted new customer-centric work environment which effectively change the bank employees' roles and job requirements as well as constantly being challenged by new expectations and requirements by the management and bank authorities. In fact, for year 2008, over RM 6.5 million was spent on training as part of commitment towards human resources optimization. Focus was also given towards nurturing future leaders through Leadership and Human Capital Development programmes.

Multiple factors were found to be closely associated with the rapidly evolving banking environment and demanding working environment which significantly influence the level of need and job satisfaction of bank employees. Among others include motivational inspirations, supervision or leadership, working environment, and competition. These developments are very important towards assisting BIMB towards catering better HRM strategies and thus helping BIMB retaining competence employees and therefore is able to achieve its vision to be the Global Leader in Islamic Banking in locally and globally.

\section{Objectives of the Study}

The research attempted to discover the bank employees' feeling in regards to their work; what frustrate and pleases them. In capturing the above phenomena, the following objectives were specifically formulated:

- To identify the factors contributing to job satisfaction level;

- To investigate the relationship between the identified independent variables such as motivational factors, reward systems, supervision and leadership, working environment, and competition with job satisfaction level.

- To determine the most influencial factor towards job satisfaction among the employees.

\section{Literature Review}

\subsection{Job Satisfaction}

Over the year, some research has shown that job satisfaction causes job performance. (Goodman, 2007). Job satisfaction is an integral part in human resources management. By identifying factors influencing job satisfaction, the management especially human resource department is able to provide necessary and meaningful information to make intelligent decision for promoting employee's job satisfaction level (Lambert et. al, 2001). Job satisfaction has been defined as a set of favorable or unfavorable feeling with which employees view their work. The feeling is very much associated with elements such as attitude and behavioral intentions which can help managers to understand employee relations to their jobs and to predict the effect on future behavior (Garman et. al., 2003). Other theories assume that the interaction of variables such as task characteristics, organizational characteristics and individual characteristics that influences job satisfaction (Hoy and Miskel, 1996) which will ultimately affect the quality of service rendered (Fitzgerald et.al. 1994)

Job satisfaction theories are categorised into content and process theories (Gruenberg, 1979). Factors influencing job satisfaction were examined by the content theory such as the Maslow Hierarchical of Needs (1954), Herzberg's Two Factors Theory (1959), and the Existence, Relatedness and Growth theory by Alderfer (1969). The Herzberg Theory is concerned with two separate sets of condition which are satisfier or motivator, and dis-satisfier or hygiene factors which are incapable of providing motivation or satisfaction. Satisfier includes the work itself, responsibility achievement, recognition, advancement and growth while dis-satisfier includes working position, interpersonal relationship, salary, status, job security, supervision, company policy and personal life (Herzberg et. al, 1959).

The process theory examine the interaction process which job satisfaction derived between variables such as expectations, needs and values. These include equity theory by Adams (1963) which examines the individual beliefs on the fair treatment received by them against their peers; Vroom's (1964) theory that suggested alternative behaviours were chosen by people based on their expectation that a particular behaviour will lead to one or more desired result; and Locke (1976) which belived that job satisfaction was influenced by employee's values such as achievement and sense of success from the job as well as increase in salary, promotion opportunities and recognition which are non-job related factors. A study by Schermerhorn et. al (2011) listed four categories of factors affecting job satisfaction including challenging jobs, equitable reward system including salary and promotional opportunities, good colleagues' relationships and conducive working environments. 
Studies on employees job satisfactions are extensively administered especially in the developed countries. In Malaysia, research was done on job satisfaction from different industrial sectors including; job satisfaction among woman managers in automobile sector (Santhapparaj et. al 2005); factors affecting job satisfaction in two automotive industries (Dawal and Taha 2006); job satisfaction and antecedent of needs among the employees of a leading bank (Lew and Liew, 2006); and factors influencing job satisfaction in two universities by Wong and Heng (2009).

\subsection{Job Satisfaction and Related Variables}

According to Crossman and Abou Zaki, (2003), the individual evaluates the situational characteristics before commencement of employment, whereas situational occurrences are evaluated afterwards. Overall satisfaction is a function of a combination of situational characteristics and situational occurrences. The situational characteristics commonly proposed as key factors in job satisfaction are: the work itself, pay, promotion, supervision and co-workers, although other variables such as employee involvement and organizational commitment may also have impact. Situational theories assume that job satisfaction is influenced by the interaction of variables such as task characteristic, organization characteristic and individual characteristic (Hoy and Miskel, 1996). Adam and King (1996) stated that there are several aspects or factors of job satisfaction that influence perception of overall job satisfaction such as career advancement opportunities, communication, management, reward and other. On the other hand, dissatisfaction will bring negative effect to organization. Organization with higher turnover and low compensation was the most common reason given for dissatisfaction.

\subsection{Demographic Factors}

The researchers were concerned with the demographic of the respondent correlation to their job satisfaction level. Demographic factors surveyed include gender, age, placement, education level, designation, salary level and tenure with the bank. Saleh \& Otis (1964) discovered that in holding the job category constant, there are positive relationship between age and job satisfaction, and negative relationship between education level and job satisfaction; and inconclusive relationship that women are more satisfied than men. Korman (1977) and Vroom (1964) both found that personal factor and working environment contributed towards job satisfaction.

Numerous studies were conducted to determine job satisfaction and demographic factors such as age, gender, tenure and education (Hickson and Oshagbemi, 1999; Oshagbemi, 1998). These studies suggested relationship but the evidences were mixed, with positive and negative relationship. Age has been identified as one of the factor affecting job satisfaction. Studies in different developing countries proved that elder workers have higher job satisfaction level than their younger counterparts (Kaya, 1995; Janson and Martin,1982).

\subsection{Motivational Factors and Reward System}

O'Reilly et. al (1980) have linked that both tasks and organisational reward contributed to job satisfaction. Intrinsic reward directly linked to jobs such as interesting and challenging work, variety and ability to use one's skills are task rewards. Tangible rewards which are visible to others such as salary, promotion and comfortable working condition are organizational rewards. Thus job satisfaction is a function of a combination of situational characteristics and situational occurrences. The situational characteristics commonly proposed as key factors in job satisfaction are: the work itself, pay, promotion, supervision and co-workers, although other variables such as employee involvement and organization commitment (Crossman \& Abou Zaki 2003). Thus, the ability to achieve and maintain high levels of motivation become a real challenge that can provide employees with the strength to combat doubt, anxiety, and uncertainty (Quick and Nelson, 2009; Stajkovic, 2006). The role of colleagues in addition further support the process of enhancing motivation of employees at workplace. (Winnie Mujah, et. al., 2011)

Compensation and benefits are important factors influencing employee retention. The major reason people working is to have income in order to fulfil basic survival needs such as food, clothing and shelter. Satisfaction through income earned further leads to employee retention. Appelbaum (1991) states that many companies today identify innovation strategies that are directly linked to improving organizational performance. There are many approaches to incentive compensation such as cash, bonuses, stock purchase and profit sharing. These can affect the worker performance as well as job satisfaction which contribute to the worker productivity.

Money, benefits, and many different forms of compensation have been used to attract, retain, and motivate employees and achieve organizational goals in the USA and around the world (Barber and Bretz, 2000; Chiu et. al., 2001; Tang et. al, 1998). The remuneration policy of a company may be used specifically to retain top workers as well as win out over competitors who have high executive turnover rates. Salary though might not inspire loyalty to an organization, is usually the single most important factors for a person's decision to join, stay 
or leave. Ronan and Organt (1973) listed salary as main factors influencing job satisfaction. Egbule (2003) study of academic staffs' job satisfaction in Nigeria was affected by salary, working condition and university status. Ronan and Organt (1973) listed salary as main factors influencing job satisfaction.

Organizations with a high pay level may attract and retain a qualified work-force (Williams and Dreher, 1992), and reduce training or recruiting costs (Holzer, 1990). It has been suggested by researchers that money is a motivator (Lawler, 1973). Many studies have investigated the relationships between compensation components and attraction, retention, and motivation of US employees (Barber and Bretz, 2000; Gerhart and Milkovich, 1992; Kahn and Sherer, 1990). Base salary is one of the main determinants that employees use when they make an employment decision (Gerhart and Milkovich, 1992).

The efficiency wage theory asserts that above-market pay can increase efficiency and reduce unit labor costs such as attracting high-quality applicants, reducing turnover and increasing work effort (Campbell, 1993; Cappelli and Chauvin, 1991). High pay influences employees' decisions in employment acceptance and intention to leave (Judge, 1993; Lawler and Jenkins, 1992). Employers use benefits to attract and retain good people; employees rely on benefits (e.g. medical subsidies, vacations, and retirement) to secure their financial wellbeing. By linking benefits (e.g. pension and holidays) to seniority, workers will be reluctant to change jobs (Gerhart and Milkovich, 1992). Generous rewards tend to retain people, lead to high satisfaction, commitment, and loyalty.

\subsection{Supervision / Leadership}

Supervisory practices are the most throughly researched of job satisfaction's variable. A large number of researches have been conducted since the initial publication of the Michigan Leadership Studies by Katz et. al., (1950) and most found that participative and involving supervisor leadership effect job satisfaction positively (Saiyadain, 1985; Lunjew et. al, 1994; Kim, 2002).

The term leadership means different things to different people. Although there is no ultimate definition of leadership exists (Yukl, 2002), the majority of definitions of leadership reflect some basic elements include, group, influence, and goal (Bryman, 1992). Leadership is associated with management, although the emphasis in leadership is on development, strategy, vision and adapting the organization to a changing environment. Management is about planning, organizing and controlling, both human and non-human, to achieve the goals and objectives (Riggs, 1997). As leadership focuses on the social exchange relationship between leaders and employees, possible outcomes such as subordinate satisfaction, supervisor satisfaction, performance, commitment, role conflict, role clarity and turnover intentions (Schermerhorn et. al. 2011; Yukl, 2002) can be observed. Staff-related tasks like delegating, informing and communicating also correlate positively with job satisfaction. Howell and Avolio (1993), suggest that an awareness of the role of leaders and the effect of leadership style provides a partial explanation for developing organizational effectiveness. This is consistent with the findings of leadership theorists who suggest that the presence of certain leadership styles may significantly influence employee motivation and ultimately company performance.

\subsection{Working Environment and Competition}

In this study, working environment refers to facilities, interior design and exterior design provided by company. Facilities are building, equipment and machinery that are provided by company for business purpose. Beside that working environment includes indoor and outdoor workplace. It is through the engagement of conducive work environement that will influence service climate and eventually influence job satisfaction. (Ram et. al, 2011). Regarding competition between the staff also give an impact to the job satisfaction. This is supported by Schemerhon, (2011) found that competitor within a form may result in a situation which one party achieve victory by having superior skill or domination. If it poorly manage, it may result to conflicts which never been resolved and may interfere with the overall performance of the staff. Greenberg \& Baron (2008) . Korman (1977) identified personal factors and working environments such as job category level, affect job satisfaction, job variety, leadership by supervisor, promotional opportunities, reward system, social interaction as well as teamwork. Hui and Yee (1999) listed down positive workgroup atmosphere resulted in higher job satisfaction collectively rather than individuals.

The creation of a good human relation activities is very much related to the management of employment relationship (Lin et., 2008). With this establishment it will further enhance the spirit of healthy competition within the firm (Andonova and Zuleta, 2007).

\section{Research Methodology and Design}

The survey methodology has been used to collect the data through distribution of questionnaires focusing on BIMB branches in three states in the East Coast region which involved Pahang, Kelantan and Terengganu. 


\section{THEORETICAL FRAMEWORK}

Independent variables
Dependent variable

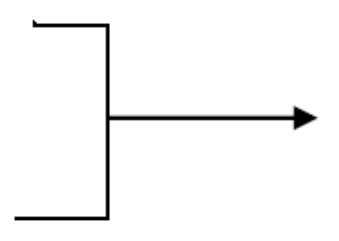

\section{Job satisfaction}

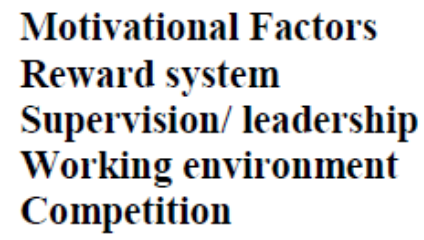

Figure 1. Research framework on job satisfaction

The dependent variable in this study is the job satisfaction level among BIMB's employees at all branches in the East Coast Region. The independent variables were motivational factors, reward systems, supervision/ leadership, working environment as well as competition.

\subsection{Hyphothesis Formulated}

Below are the hypotheses built with relationship indicated as follows:

Hypothesis 1: There is a significant relationship between motivational factors and job satisfaction among employees in BIMB.

Hypothesis 2: There is a significant relationship between reward system and job satisfaction among employees in BIMB.

Hypothesis 3:There is a significant relationship between supervision/ leadership and job satisfaction among employees in BIMB.

Hypothesis 4: There is a significant relationship between working environment and job satisfaction among employees in BIMB.

Hypothesis 5: There is a significant relationship between competition and job satisfaction among employees in BIMB.

Hypothesis 6: All the selected independent variables are able to explain job satisfaction among employees in BIMB.

\subsection{Instrumentation and Data Collection Method}

The questionnaires were distributed directly to the employees of BIMB. Prior to that, a set of 30 questionnaires were distributed to BIMB Regional Office, Terengganu, as a pilot study. Meanwhile, 382 set of questionnaires were distributed to all branches in the East Coast and 206 sets of questionnaires were returned.The questionnaires were divided into seven (7) sections. Section A: Demographic factors; Section B: Motivational factors; Section C: Reward system; Section D: Supervision/ Leadership; Section E: Working environment; Section F: Competition; Section G: Job satisfaction. For Section A, a set of nominal scaled questions has been designed for capturing respondent's profile and demographic data including gender, branch, age, educational qualification, position, salary level and working experience with BIMB. For Section B, C, D, E, F and G, the questions were measured using 5-point Likert Scale. It used to determine whether respondents are satisfied with the questions asked. The questionnaires were designed to capture the differences between demographic factors, motivational factors, reward systems, supervision/ leadership, working environment and competition with job satisfaction.

\subsection{Sampling Procedures}

The population of this study is all employees in BIMB, Eastern Corridor Regional Office and all branches in the East Coast i.e. Pahang, Terengganu and Kelantan. The total population for Eastern Corridor Regional Office is 60 employees and 392 employees for all branches in East Coast i.e. Pahang, Terengganu and Kelantan.

The sample size of 236 respondents was selected to represent the whole population found to be adequate (Sudman, 1976). The sampling frame for this study was taken from the population that was generated by BIMB, Eastern Corridor Regional Office and all branches in the East Coast i.e. Pahang, Terengganu and Kelantan for the year 2010. The execution of sampling method used quota sampling technique. The data were collected through distribution of questionnaires focusing on three (3) states in East Coast, i.e., Pahang, Kelantan and 
Terengganu. Then, it was narrowed down to all branches under the three (3) states which comprise of eight (8) BIMB branches in Pahang, nine (9) BIMB branches in Kelantan and four (4) BIMB branches in Terengganu. For BIMB, Eastern Corridor Regional Office, Terengganu, the questionnaires were distributed according to different departments i.e. Credit Administration Centre, Commercial Banking Division, Consumer Recovery Division, and Business Recovery Division. The final stage of sampling was executed by using the purposive approach.

\section{Findings and Data Analysis}

\subsection{Reliability Analysis}

The researcher has used reliability analysis to measure the consistency and stability of data that researcher obtained from questionnaire. A value that indicates less than 0.6 is poor. Table 1 shows the result of the reliability test. The result of Cronbach's Alpha before being adjusted for independent variables in section, C, D, E were $0.926,0.945$ and 0.913 respectively and for Section G also shows high reliability which is 0.932 . However, in order to avoid the multicollinearity problem, the researcher has adjusted and deleted a few questions for every section to obtain a much reliable inter-item measurement. The result of Cronbach's Alpha for all the adjusted variables in Section B, C, D, E, F and G were 0.874, 0.897, 0.878, 0.888, 0.830 and 0.895 respectively. Following the suggestion by Sekaran (2008), all items measuring the variables were considered to be very good and acceptable.

Table 1. Table of alpha coeffient range

\begin{tabular}{lccccc}
\hline VARIABLES & $\begin{array}{c}\text { Nonadjusted } \\
\text { Cronbach alpha }\end{array}$ & $\begin{array}{c}\text { TOTAL } \\
\text { ITEM }\end{array}$ & $\begin{array}{c}\text { Adjusted } \\
\text { Cronbach alpha }\end{array}$ & $\begin{array}{c}\text { TOTAL } \\
\text { ITEM }\end{array}$ \\
\hline $\mathrm{G}$ & JOB SATISFACTION & 0.932 & 11 & 0.895 & 8 \\
$\mathrm{~B}$ & MOTIVATIONAL FACTORS & 0.874 & 9 & 0.874 & 9 \\
$\mathrm{C}$ & REWARD SYSTEMS & 0.926 & 15 & 0.897 & 12 \\
$\mathrm{D}$ & SUPERVISION/ LEADERSHIP & 0.945 & 10 & 0.878 & 5 \\
$\mathrm{E}$ & WORKING ENVIRONMENT & 0.913 & 13 & 0.888 & 11 \\
$\mathrm{~F}$ & COMPETITION & 0.83 & 5 & 0.83 & 5 \\
\hline 6.2 Frequency Analysis & & & &
\end{tabular}

The distribution of respondents profile were in terms of gender, branch, age, educational background, position, salary level and working experience. As per in Table 2, the summary of respondents for this study according to their profiles in terms of frequency and percentage. Based on gender, most of the respondents were female which accounted for $127(53.8 \%)$ and $108(45.8 \%)$ respondents represented by male employees.

Table 2. Summary of the respondent for this study according to their profile

\begin{tabular}{|c|c|c|c|c|c|}
\hline Category & Freq & $\%$ & Category & Freq & $\%$ \\
\hline Gender & \multicolumn{5}{|c|}{ Education Qualification } \\
\hline Male & 108 & 45.8 & MCE & & \\
\hline Female & 127 & 53.8 & Diploma & 78 & 33.1 \\
\hline Missing & 1 & 0.4 & Degree & 85 & 36 \\
\hline State & & & Master & 66 & 28 \\
\hline Pahang & 69 & 29.2 & Phd & 4 & 1.7 \\
\hline Kelantan & 88 & 37.3 & Missing & 3 & 1.3 \\
\hline Terengganu & 79 & 33.5 & Salary level & & \\
\hline Position & & & RM2,000\& $<$ & 84 & 35.6 \\
\hline Non executive & 129 & 54.7 & RM2,001-RM4,000 & 114 & 48.3 \\
\hline Executive & 80 & 33.9 & RM4,001 - RM6,000 & 31 & 13.1 \\
\hline Managerial & 26 & 11 & RM6,001 and above & 5 & 2.1 \\
\hline Missing & 1 & 0.4 & Missing & 2 & 0.8 \\
\hline Age & & & Working experience & & \\
\hline 30 years \& below & 112 & 47.5 & $1-3$ years & 63 & 26.7 \\
\hline 31 years -40 years & 91 & 38.6 & $3-7$ years & 67 & 28.4 \\
\hline 41 years -50 years & 27 & 11.4 & $7-10$ years & 23 & 9.7 \\
\hline Above 50 years & 5 & 2.1 & $10-15$ years & 40 & 16.9 \\
\hline Missing & 1 & 0.4 & 15 years and above & 41 & 17.4 \\
\hline & & & Missing & 2 & 0.8 \\
\hline
\end{tabular}

Exchange Rate: USD 1 = RM 3.1 
For the institutions profile, the state of Kelantan, Terengganu, and Pahang were represented with the total of $37.3 \%, 33.5 \%$ and $29.3 \%$ respectively. From the frequency result obtained, it was found that there were $47.5 \%$ respondents categorized under age range of 30 years and below, $38.6 \%$ between 32 years to 40 years old, $11.4 \%$ made up of those between the age range of 41 years to 50 years old, and $2.1 \%$ were from the age range of 50 years and above. As for the educational qualification, it was found that the highest qualification in BIMB was Diploma certificate qualificatio with $36 \%$, followed by MCE /SPM qualification at $33.1 \%$, the Degree holders were represented by $28 \%$, while the Postgraduate Degree holders comprise of $3 \%$.

The position levels have been regrouped to three (3) main group which were managerial level (regional head, head, manager, deputy manager, branch manager and branch operation manager), executive level (assistant manager and executive officer) and non-executive level (chief clerk and clerk). From the data collected, the highest frequency for non-executive level were $54.7 \%$. While the lowest frequency was among those of the managerial level represented by $11 \%$ respondents and the executive level was $33.9 \%$ represented.

The review result of salary level indicated that the highest frequency of salary level was within the salary range of RM2,001 - RM4,000, which stood for $48.3 \%$. While the lowest frequency was within the salary range of RM6,001 and above, represented only $2.1 \%$ respondents. The salary range for RM2,000 and below had the frequency result of $35.6 \%$, followed $b$ the salary range of RM4,001 - RM6,000 at $13.1 \%$. The profile of working experience displayed that most of the respondents $(26.7 \%)$ have been working for $1-3$ years, a figure of $28.4 \%$ was for those having been worked for $3-7$ years, $28.4 \%$ who have been working for $7-10$ years, $9.7 \%$ have been working $10-15$ years, and $17.4 \%$ for those serving more then 15 years.

\subsection{Correlation Coefficient Analysis}

The Correlation Analysis attempted to explain the existence of significance as well as the strength of relationship between the independent variable (motivation, reward system, supervision/ leadership, working environment and competition) and dependent variable (job satisfaction level). The rules of thumb have been proposed to characterize the strength of the association between the above variables. Table 3 displayed the result of the relationship. The result revealed that the independent variables were statistically significant at the $p$-value of 0.000 for all variables. The analysis on the strength association suggested that competition extracted the pearson value of $r=0.664$ indicating this section was at the stage of substantial to very strong, followed by the working environment with $\mathrm{r}=0.646$, and reward system, $\mathrm{r}=0.628$. Both sections also indicated the variables are in the stage of substantial to very strong. Then followed by motivational factors with $r=0.552$, and section $D$, which was supervision / leadership with $\mathrm{r}=0.550$.

Table 3. Summary of pearson correlation

\begin{tabular}{rccccc}
\hline Variable: & $\begin{array}{c}\text { Motivational } \\
\text { Factors }\end{array}$ & $\begin{array}{c}\text { Rewards } \\
\text { Systems }\end{array}$ & $\begin{array}{c}\text { Supervision } \\
\text { leadership }\end{array}$ & $\begin{array}{c}\text { Working } \\
\text { Environment }\end{array}$ & Competition \\
\hline Pearson Corr & .552 & .628 & .550 & .646 & .664 \\
Sig value & .000 & .000 & .286 & .000 & .000 \\
\hline
\end{tabular}

6.4 Multiple Regression Analysis

Table 4 summarized the Multiple Regression analysis among all independent variables towards job satifaction level, the dependent variable. Among all the independent variables, competition variable in Section F, gave the highest contribution towards the dependent variable with $t$-value of 6.151 and beta score 0.327 , followed by working environment variable in section E, which indicated the t-value of 5.166 and beta score of 0.301 . Then, the reward system indicated the t-value of 4.153 and beta score of 0.233 . The ranking followed by the motivational factors, with t-value of 2.488 and beta score of 0.128 , and lastly, the supervision/ leadership, with t-value of 0.243 and beta score of 0.014 . According to the rule of thumb, when t-value is 2 or more, there were four independent variables (motivational factors, reward system, working environment, and competition ) which demonstrated to be significant in this study, while variables concerning supervision/ leadership was not significant. 
Table 4. Summary of multiple regression analysis

\begin{tabular}{|c|c|c|c|c|c|c|}
\hline \multicolumn{7}{|c|}{ coefficients } \\
\hline & \multirow[t]{2}{*}{ Model } & \multicolumn{2}{|c|}{ Unstandardized Coefficients } & \multirow{2}{*}{$\begin{array}{c}\text { Standardized Coefficients } \\
\text { Beta }\end{array}$} & \multirow[b]{2}{*}{$\mathrm{t}$} & \multirow[b]{2}{*}{ Sig. } \\
\hline & & B & Std. Error & & & \\
\hline 1 & (Constant) & .038 & .212 & & .178 & .859 \\
\hline & MOTIVATIONAL FACTOR & .139 & .056 & .128 & 2.488 & .014 \\
\hline & REWARD SYSTEMS & .221 & .053 & .233 & 4.153 & .000 \\
\hline & $\begin{array}{l}\text { SUPERVISION/ } \\
\text { LEADERSHIP }\end{array}$ & -.013 & .055 & -.014 & -.243 & .808 \\
\hline & ENVIRONMENT & .365 & .071 & .301 & 5.166 & .000 \\
\hline & COMPETITION & .304 & .049 & .327 & 6.151 & .000 \\
\hline
\end{tabular}

a. Dependent Variable: JOB SATISFACTION

Moreover, based on Table 5, the coefficient of determination or formerly known as R-Squared (R) represents the value of 0.788 . The score generated thus explained that $78.8 \%$ of the variation in this model was able to be explained by all the independent variables whereas the remaining $21.1 \%$ was unexplained. In this analysis, it can be viewed that among five independent variables, the competition played the most influential role in deriving job satisfaction among employees in BIMB. It was supported based on the highest $\mathrm{t}$-value and beta score as compared to other independent variables used in this study. The result from Regression Analysis displayed that there were significant relationship for four (4) independent variables i.e. motivational factors, reward system, working environment and competition that had $t$-value of $>2$. Only supervision/ leadership factors showed $\mathrm{t}$-value of $<2=-.243$. Hence, hypothesis 6 was supported.

Table 5. Model summary

\begin{tabular}{rlrrrc}
\hline Model & R & \multicolumn{1}{c}{ R Square } & Adjusted R Square & F Change & Sig. \\
\hline 1 & 0.788 & 0.620 & 0.612 & 75.211 & .000
\end{tabular}

Predictors: Competition, Motivational factors, Supervision/leadership, Reward, working environment.

\subsection{Cross-Tabulation between Position and Job Satisfaction}

The table above shows the cross-tabulation between position level of respondents and job satisfaction level. From the table, it clearly indicated that the respondents were from non-executive level were represented with 129 respondents of the total 226 samples. Of the total, 95 respondents or $40.43 \%$ agreed or were satisfied working in BIMB. Besides, 32 respondents or $13.62 \%$ were not sure whether they were satisfied or not and only 2 respondents disagreed or were not satisfied working in BIMB with the percentage of $0.85 \%$. The table also showed that the respondents for executive level, that were 95 respondents or $40.43 \%$ agreed or were satisfied working in BIMB, whereas 32 respondents or $13.62 \%$ were not sure whether they were satisfied or not and only 2 respondents or $0.85 \%$ respondent disagreed or were not satisfied working in BIMB. Furthermore, 25 respondents or $10.64 \%$ agreed for the managerial level, followed by those who were not sure whether they are satisfied or not for only 1 respondent or $0.43 \%$.

\subsection{Cross-Tabulation between Working Experience and Job Satisfaction}

The Cross-Tabulation Analysis indicated that the respondents 19.23\% with working experience of 1 to 3 years were satisfied working with BIMB, $7.26 \%$ were not sure whether they were satisfied and only $1(0.43 \%)$ of the respondent was not satisfied. The result further shows that $20.09 \%$ of the respondents with working experience of 3 to 7 years were satisfied working in BIMB, whereas $7.69 \%$ are not sure whether they are satisfied or not and only 2 respondents or $0.85 \%$ were not satisfied working with BIMB. Furthermore, $8.12 \%$ of those with working experience of 7 to 10 years indicated their satisfaction, followed by $1.28 \%$ were not sure of their satisfaction and 1 respondent that disagreed of the satisfaction. For the respondents that have had working experience of 10 to 15 years, $14.5 \%$ of the total respondents agreed on the job satisfaction level with the percentage of $14.53 \%$, followed by $2.56 \%$ were not sure and none was not satisfied. Of those that have been working more than 15 years, $15.38 \%$ agreed with the job satisfaction level, $2.14 \%$ were not sure of the satisfaction with their job and non indicated dissatisfaction. 


\section{Discussion and Conclusion}

The main aim of this paper was to discuss the relationship among the variables used and measure the level of significance. By using Pearson Correlation Analysis the result suggested that competition is the most influential construct associate with job satisfaction level among the employees, followed by working environment, reward system, motivational factors and supervision and leadership. However, further analysis using Multiple Regression, revealed that only four (4) independent variables were significant in this analysis which were competition, working environment, reward system and motivational factors. While supervision/ leadership factors was not significant. This paper also attempted to identify the most important dimensions in predicting job satisfaction level among the employees. Again the result of the regression displayed that competition was the leading element impacting job satisfaction among the employees in BIMB.

The implication of the study provided two interesting findings. The first one was the consistentcy of competition in promoting satisfaction. The second implication revealed that the impact of supervision or leadership on satisfaction level which was relevant if measured by itself, but may not be that significant if other elements mentioned in this study were to be accounted altogether. Nevertheless the result shown by $\mathrm{R}$ square value implied that $78.8 \%$ of the variation in the model can be explained by all the independent variables and the remaining $21.2 \%$ was explained by other factors which were not included in this research model. The combined effort of the selected elements involving motivational efforts (intrinsic values), reward system (extrinsic values), supervision or leadership, working environment, and competition were still very relevant to promote job satisfaction among the BIMB employees.

\subsection{Motivational Factors and Rewards System}

The motivational factors result represented moderately substantial correlation. Majority of respondents agreed that the motivational factors influence the job satisfaction level among employees in BIMB. Elements such as recognition can lead to employee's job satisfaction. Recognition can be in the form of monetary recognition or certificates and others. It will improve the overall job satisfaction and in turn ensures employees superior performance and eventually reflect the good image and reputation of BIMB through its outstanding achievement. The result was further supported with the role of equitable rewards which thus provides a good mixture in promoting job satisfaction.

\subsection{Supervision or Leadership}

The leadership style or approach has crucial influence on the job satisfaction level in BIMB. Our finding revealed its contribution. Due to that reason, BIMB management needs to pay attention on characteristic of a good leader, relationship between the group leader and his or her subordinates, the fair distribution of workloads by the supervisors or head of department, etc. The two -way communications between a leader and the staff can solve many internal problems and bottleneck in the organization. In addition, the concept of employee empowerment through the practice of enriching job which employees need to plan and control their work, giving responsibility and authorities to make decision regarding their task helps them take ownership of their job, provide avenue for increasing job satisfaction.

\subsection{Working Environment}

The result of the analysis for working environment variable demonstrated that the working environment also has a moderately strong relationship with job satisfaction and is discovered to be significant. The creation of Motivating Working Environment therefore remain essential. The environment of workplace act as one of the important factors in determining the employees comfortability, offering pleasant condition which ultimately improve performance and job satisfaction. A good interior and exterior design will influence the performance of employee as well as increase productivity. On the other hand, workload, monotonous tasks and lost job flexibility are among the symptoms that lead to job stress and bring a negative affect to the performance of employees. Thus, the equitable office space such as office layout, climate condition (color walls, lighting, temperature) and providence of recreational space can help in reducing stress.

\subsection{Competition}

The result of the analysis for competition in this study shows that this variable is significant and the relationship is found to be in the range of substantial to very strong relationship towards job satisfaction. We strongly suggest that the management of BIMB should continuosly encourage positive competition within the bank or its branches so that each employee could strive for been a peak performer and excellent in their jobs. Other than that, BIMB management needs to encourage external competition, i.e., with other Islamic financial institutions to stay competitive in banking industry. 


\section{Future Research Direction}

Findings of this study should not be generalized across all bank employees in Malaysia as the result is restricted towards an Islamic Banking institution as well as demographic concentrated in the East Coast of Peninsular Malaysia only. The researcher also recommended for future studies to be pursued further on different facet of job satisfaction variables and across different banking sector in Malaysia.

\section{References}

Adam, G. A., \& King, B. D. (1996). Relationship of job and family involvement with job and life satisfaction. Journal of Applied Psychology, 81(4), 411-420. http://dx.doi.org/10.1037/0021-9010.81.4.411

Adams, J. S. (1963). Towards an understanding of inequity. Journal of Abnormal and Social Psychology, 67(5), 422-436. http://dx.doi.org/10.1037/h0040968

Alderfer, C. P. (1969). An empirical test of a new theory of human needs. Organizational Behavior and Human Performance, 4(2), 142-175. http://dx.doi.org/10.1016/0030-5073(69)90004-X

Andonova, V., \& Zuleta, H. (2007). The effect of enforcement on human resources practices. International Journal of Manpower, 28(5), 344-53. http://dx.doi.org/10.1108/01437720710778358

Appelbaum, H. S. (1991). Compensation strategy determinants in high technology organization. International Journal of Manpower Management, 12(8), 31-39.

Aziz, A. Z. (2004). Towards world-class banking: efficient, effective and resilient system. Bank Negara Malaysia Governors' Keynote Address at the Malaysian Banking Summit 2004, Kuala Lumpur.

Barber, A. E., \& Bretz, R. D. (2000). Compensation, attraction, and retention. In Rynes, S. L. \& Gerhart, B. (Eds.), Compensations in Organizations: Current Research and Practice, Jossey-Bass. San Francisco, California.

Bowers, T., Gibb, G., \& Wong, J. (2003). Banking in Asia: Acquiring a Profit Mindset (2nd Ed ). John Wiley and Sons (Asia) Singapore.

Campbell, C. M. (1993). Do firms pay efficiency wages? Evidence with data at the firm level. Journal of Labor Economics, 11(3), 442-469. http://dx.doi.org/10.1086/298303

Cappelli, P., \& Chauvin, K. (1991). An interplant test of the efficiency wage hypothesis. Quarterly Journal of Economics, 106(3), 769-787. http://dx.doi.org/10.2307/2937926

Chiu, R. K., Luk, V. W. M., \& Tang, T. L. P. (2001). Hong Kong and China: the cash mentality revisited. Compensation and Benefits Review, 33(3), 66-72. http://dx.doi.org/10.1177/08863680122098324

Crossman, A., \& Abou Zaki, B. (2003). Job Satisfaction and Employee Performance of Lebanese Banking Staffs. Journal of Managerial Psychology (UK), 18(4), 368-377. http://dx.doi.org/10.1108/02683940310473118

Dawal, S. Z., \& Taha Z. (2006). Factors Affecting Job Satisfaction in Two Automotive Industries in Malaysia. Journal Teknologi, 44(A), 65-80.

Egbule, P. E. (2003). Factors related to job satisfaction of academic staff in Nigerian universities. Journal of Further and Higher Education, 27(2), 157-166 http://dx.doi.org/10.1080/0309877032000065172

Fitzgerald, L., Johnson, R., Brignall, S., Silvestro, R., \& Ross, C. (1994), Performance Measurement in Service Business. The Chartered Institute of Management Accountants, Cambridge.

Garman, A. N., Davis-Lenane, D., \& Corrigan, P. W. (2003). Factor structure of the transformational leadership model in human service teams. Journal of Organizational Behavior, 24(6), 803-812. http://dx.doi.org/10.1002/job.201

Gerhart, B., \& Milkovich, G. T. (1992). Employee compensation: research and practice. In Dunnette, M.D., Hough, M. (Eds.), Handbook of Industrial and Organizational Psychology (pp. 481-570). Consulting Psychologists Press, Palo Alto, California.

Goodman, S. H., Fandt, P. N., Michlitsch, J. R., \& Lewis, P. S (2007). Management: Challenges For Tomorrow's Leaders. South-Western Language Learning.

Greenberg, J., \& Baron, R. A. (2008). Behaviour in Organizations (9th Ed). Pearson International, New Jersey, U.S.A.

Gruneberg, M. M. (1979). Understanding Job Satisfaction. The Maximillian Press Ltd., London.

Herzberg, F., Mausner, B., \& Synderman B. B. (1959). The Motivation to Work. Wiley \& Sons Inc. New York. 
Hickson, C., \& Oshagbemi, T. (1999). The effect of age on the satisfaction of academics with teaching and research. International Journal of Social Economics, 26(4), 537-54. http://dx.doi.org/10.1108/03068299910215960

Howell, J. M., \& Avolio, B. J. (1993). Transformational leadership, locus of control and support for information: key predictors of consolidated-business-unit performance. Journal of Applied Psychology, 78(6), 891-902. http://dx.doi.org/10.1037/0021-9010.78.6.891

Hoy, W. K., \& Miskel, C. E. (1996). Educational Administration: Theory, Research and Practice. McGraw-Hill, New York.

Hui, C. H., \& Yee, C. (1999). The impact of Psychological Collectivism and Workgroup Atmosphere on Chinese Employee's Job Satisfaction. Journal of Applied Psychology, 74(2), 201 - 207.

Ivanacevich, J. M. (2007). Human Resource Management. McGrawHill International Edition, New York.

Janson, P., \& Martin, J. K. (1982). Job Satisfaction and Age: A Test of Two Views. Social Forces, 60(4), 1089-1102.

Judge, T. A. (1993). Does affective disposition moderate the relationship between job satisfaction and voluntary turnover? Journal of Applied Psychology, 78(3), 395-401. http://dx.doi.org/10.1037/0021-9010.78.3.395

Kahn, L. M., \& Sherer, P. D. (1990). Contingent pay and managerial performance. Industrial and Labor Relations Review, 43(3), 1075-1205. http://dx.doi.org/10.2307/2523574

Katz, D., Maccoby, \& Morse, N. (1950). Productivity, Supervision and Morale in an Office Situation. Ann Arbor, Michigan, Institute for Social Research.

Kaya, E. (1995). Job Satisfaction of the Librarians in the Developing Countries. 61st IFLA General Conference, Istanbul, Turkey.

Kim, S. (2002). Participative management and job satisfaction: Lessons for management and leadership. Public Administration Research, 62(2), 391-401. http://dx.doi.org/10.1111/0033-3352.00173

Korman, A. K. (1977). Organizational Behaviour. Prentice-Hall Inc. New Jersey.

Lambert, E. G., Hogan, N. L., \& Barton, S. B. (2001). The impact of job satisfaction on turnover intent: a test of a structural measurement model using a national sample of workers. The Social Science Journal, 38(2), 233-250. http://dx.doi.org/10.1016/S0362-3319(01)00110-0

Lawler, E. E., \& Jenkins, G. D. (1992). Strategic reward systems. In Dennette, M.D., Handbook of Industrial and Organizational Psychology. Consulting Psychologists Press, Palo Alto, California.

Lew, T. Y., \& Liew, M. Y. (2006). Exploring the antecedents of needs and job satisfaction among employees of a leading bank in Malaysia: Implications for managing bank employees in Malaysia. Banker's Journal Malaysia, 29(1), 10-26.

Lin, C. H., Peng, C. H., \& Kao, D. (2008). The innovativeness effect of market orientation and learning orientation on business performance. International Journal of Manpower, 29(8), 752-772. http://dx.doi.org/10.1108/01437720810919332

Locke, E. A. (1976). The nature and causes of job satisfaction. In M. D. Dunnette (Ed.), Handbook Industrial and Organizational Psychology. Rand McNally College Publishing Company, Chicago.

Lunjew, M. D., Sail, R. M., \& Silong, A. D. (1994). Factors associated with employee participation and its relationship with performance and job satisfaction. Malaysian Management Review, 29(3), 42-55.

Maslow, A. H. (1954). Motivation and Personality. Harper and Row, New York.

O’Reilly, C. A., Parlette, G. N., \& Bloom, J. R. (1980). Perceptual measures of task characteristics: The biasing effects of differing frames of reference and job attitudes. Academy of Management Journal, 23(1), 118-131. http://dx.doi.org/10.2307/255499

Oshagbemi, T. (1998). The Impact of age on the job satisfaction of university teachers. Research in Education, 59(1), 95-108.

Quick, J. C., \& Nelson, D. L. (2009). Principles of Organizational Behavior (6th ed.). South-Western Cengage Learning, USA. 
Ram, P., Bhargavi G. S., \& Prabhakar, G. V. (2011). Work Environment, Service Climate, and Customer Satisfaction: Examining Theoretical and Empirical Connections. International Journal Of Business and Social Science, 2(20), 121-132.

Riggs, D. J. (1997). What's in store for academic libraries? Leadership and management issues. Journal of Academic Librarianship, 23(1), 2-8. http://dx.doi.org/10.1016/S0099-1333(97)90065-3

Ronan, W. W., \& Organt, G. J. (1973). Determinants of pay and pay satisfaction. Personnel Psychology, 26(4), 503 - 520. http://dx.doi.org/10.1111/j.1744-6570.1973.tb01153.x

Saiyadain, M. S. (1985). Personal Characteristics and Job Satisfaction: India-Nigeria comparison. International Journal of Psychology, 20(2), 143 - 153. http://dx.doi.org/10.1080/00207598508247728

Saleh, S. D., \& Otis, J. L. (1964). Age and level of job satisfaction. Personnel Psychology, 17(4), 425-430. http://dx.doi.org/10.1111/j.1744-6570.1964.tb00077.x

Santhapparaj, A. S., Srineevasan, J., \& King, K. L. (2005). Job Satisfaction Among Women Managers in Malaysian Automobile Manufacturing Sector. Journal of Applied Science, 5(9), 153-158.

Schermerhorn Jr., J. R. Hunt, J. G., Osborn, R. N., \& Uhl-Bein, M. (2011). Organizational Behavior (11th ed.). John Wiley \& Sons Inc. Pennsylvania USA.

Stajkovic, A. D., (2006). Development of a Core Confidence- Higher Order Construct. Journal of Applied Psychology, 91(6), 1208-1224. http://dx.doi.org/10.1037/0021-9010.91.6.1208

Sudman. (1976). Applied Sampling. Academic Press, New York.

Tang, T. L. P., \& Ibrahim, A. H. S. (1998). Importance of human needs during retrospective peacetime and the Persian Gulf War mideastern employees. International Journal of Stress Management, 5(1), 25-37. http://dx.doi.org/10.1023/A:1022902803386

Vroom, V. H. (1964). Work and Motivation. John Wiley and Sons, New York.

Williams, M. L., \& Dreher, G. (1992). Compensation system attributes and applicant pool characteristics, Academy of Management Journal, 35(3), 571-95. http://dx.doi.org/10.2307/256487

Winnie Mujah, Rose Ruziana Abd. Samad, Sigh, H., \& D’ Cruz, O. T. (2011). Meaning Of Work and employee Motivation. Terengganu International management and Business Journal, 1(2), 18-26.

Wong, E. S. K., \& Heng T. N. (2009). Case study of factors influencing job satisfaction in two Malaysian universities. International Business Research, 2(2), 86-98.

Yulk, G. (2002). Leadership in Organizations (5th Ed.). Prentice-Hall, Englewood Cliffs, New Jersey. 